\title{
Mineral-nitrogen supplementation to finishing Nellore steers in deferred pasture
}

\author{
Suplementação mineral-nitrogenada para terminação de novilhos Nelore em pastagem \\ diferida
}
ÍTAVO, Luis CarlosVinhas ${ }^{1 *}$; DIAS, Alexandre Menezes ${ }^{1}$; ÍTAVO, Camila Celeste Brandão Ferreira $^{1}$; FRANCO, Gumercindo Loriano ${ }^{1}$; MORAIS, Maria da Graça ${ }^{1}$; SOUZA, Andréa Roberto Duarte Lopes ${ }^{1}$; NOGUEIRA, Ériklis ${ }^{2}$; MATEUS, Rodrigo Gonçalves $^{3}$; ARAUJO, Hilda Silva ${ }^{4}$; MORAES, Gabriella Jorgetti de ${ }^{4}$; COSTA, Marlova Cristina Mioto da ${ }^{4}$; GUIMARÃES-INÁCIO, Alexandre ${ }^{4}$; NIWA, Marcus Vinicius Garcia ${ }^{4}$

\author{
${ }^{1}$ Universidade Federal de Mato Grosso do Sul, Faculdade de Medicina Veterinária e Zootecnia, Campo \\ Grande, Mato Grosso do Sul, Brasil. \\ ${ }^{2}$ Embrapa Pantanal, Corumbá, Mato Grosso do Sul, Brasil. \\ ${ }^{3}$ Universidade Católica Dom Bosco, Campo Grande, Mato Grosso do Sul, Brasil. \\ ${ }^{4}$ Universidade Federal de Mato Grosso do Sul, Faculdade de Medicina Veterinária e Zootecnia, Programa \\ de Pós-Graduação em Ciência Animal, Campo Grande, Mato Grosso do Sul, Brasil. \\ *Endereço para correspondência: luis.itavo@ufms.br
}

\section{SUMMARY}

The objective of this study was to evaluate the effects of two protein levels in mineral-proteinenergy supplements on the productivity and economic performance of Nellore steers. Ninety animals weighing $382.35 \pm 32.95 \mathrm{~kg}$ on average, were treated with mineral-nitrogen supplements containing $30 \%$ crude proteins (CP; 75\% ground maize, $8.91 \%$ urea and $16.09 \%$ mineral) and $40 \% \mathrm{CP}$ (66.67\% ground maize, $11.90 \%$ urea, and $21.43 \%$ mineral). The animals were housed in two paddocks of Uruchloa brizantha 'MG-5' (syn. Brachiaria brizantha) and were weighed at the beginning, at 45 days, and at 94 days of the experiment, when they were slaughtered at an average weight of $451 \pm 35.38$ $\mathrm{kg}$. We evaluated supplement intake, weight gain and economic aspects. The 40 and $30 \% \mathrm{CP}$ treatments significantly affected supplement intake $(\mathrm{P}<0.05)$, with averages of 0.69 and 2.26 $\mathrm{kg} /$ day, respectively. The average total weight gain was higher $(\mathrm{P}<0.01)$ in animals receiving the supplement containing $30 \% \mathrm{CP}(71.46 \mathrm{~kg} /$ animal) than in animals receiving 40\% CP (64.33 kg/animal). Greater slaughter weight was attained in the animals treated with $30 \% \mathrm{CP}$ (456.66 vs. $443.84 \mathrm{~kg}$ ). The mineral-nitrogen supplementation in both $\mathrm{CP}$ levels provided satisfactory animal performance and carcass characteristics. Owing to economic considerations, it is recommended to use $40 \%$ CP mineral-nitrogen supplements on finishing steers on pasture, although success in reducing production costs of livestock ultimately depends on the variations in prices between the different regions of the country and market opportunities.

Keywords: Brachiaria, costs, Nellore, performance, Uruchloa

\section{RESUMO}

Objetivou-se avaliar o efeito de dois teores de proteína bruta no suplemento mineralnitrogenado para terminação de novilhos Nelore. Foram utilizados 90 animais, com peso médio inicial de $382,35 \pm 32,95 \mathrm{~kg}$, submetidos a dois tratamentos: suplemento com $30 \%$ de proteína bruta (75\% de milho, $8,91 \%$ ureia e $16,09 \%$ mineral) e $40 \%$ de proteína bruta (66,67\% de milho, $11,90 \%$ ureia e $21,43 \%$ mineral). Os animais foram mantidos em dois piquetes de Uruchloa brizantha cv. MG-5 (sin. Brachiaria brizantha). Foram realizadas pesagens ao início, aos 45 e aos 94 dias de experimento, quando foram abatidos com 
$451,1 \pm 35,38 \mathrm{~kg}$. Foi avaliado o consumo de suplemento, o ganho de peso e variáveis econômicas. Houve efeito do tratamento sobre o consumo de suplemento $(\mathrm{P}<0,05)$, com médias de $0,69 \pm 0,21(40 \% \mathrm{~PB})$ e $2,26 \pm 0,52(30 \% \mathrm{~PB})$ $\mathrm{kg} /$ dia. A média de ganho de peso total foi superior $(\mathrm{P}<0,01)$ para os animais que receberam suplemento com $30 \% \mathrm{~PB}(71,46$ vs $64,33 \mathrm{~kg} /$ animal). Foi obtido maior peso de abate nos animais do tratamento com $30 \%$ PB (456,66 vs. 443,84 kg). Em ambos tratamentos, o desempenho e as caracteristicas de carcaça foram satisfatórios. Sob o ponto de vista econômico, recomenda-se a suplementação com $40 \%$ PB na terminação de novilhos em pastagens, porém o sucesso para redução dos custos de produção no campo depende das variações entre as cotações nas diferentes regiões do país e mercado de oportunidades.

Palavras-chave: Brachiaria, custos, desempenho, Nelore, Uruchloa

\section{INTRODUCTION}

Tropical pastures vary in quantity and quality throughout the year, with two well-defined production periods occurring in the rainy and dry seasons. Grass is the basis of cattle feeding, and the availability of nutrients depends on pasture biomass (SHIO et al., 2011; PROHMANN et al., 2012).

One management strategy that can guarantee forage availability during the dry season is deferred pastures, which consists of sealing a pasture area at the end of the wet period for use during drought (SILVA et al., 2009). The forage produced in this system is of low quality, with low protein and high fiber content, making it is necessary to intervene in the nutritional management of animals with supplementary diets, to overcome deficiencies, and adequately meet nutritional requirements and guarantee performance (PAULINO et al., 2001). Feed supplementation for beef cattle is intended to supplement the nutritional deficiencies of forage and thus improve the utilization of pasture (GÓES et al., 2003).

Nutrient intake via supplementation can target differentiated levels of performance by animals, and can lead to weight maintenance or even moderate gains of between 200 and 300 g/animal/day (MATEUS et al., 2011). Although production varies in pasture cattle production systems using supplementation, they are a viable option and allow significant improvements in productivity indices.

In this sense, supplementation for cattle in pastures has been researched as an alternative to improve performance, and recommendations have been established in the literature in different production situations (ÍTAVO et al., 2008; REIS et al., 2009; SANTOS et al., 2009; MORAES et al., 2010). Choosing the proper strategy of supplementation and its economic results must be among the first goals to consider (LIMA et al., 2012).

According to Silva et al. (2009) an adequate supplementation strategy should maximize the intake and digestibility of the available fodder. However, supplementation levels above $0.8 \%$ of body weight (BW) should be investigated for possible negative effects. To avoid such problems, the objective of this study was to evaluate the effects of two crude protein (CP) content levels in mineral nitrogen supplements containing two maize and urea combinations with 30 and $40 \% \mathrm{CP}$ on the productive and economic performance of the steers on deferred pastures of Uruchloa brizantha 'MG-5' (syn. Brachiaria brizantha), during the months of June to September (dry season). 


\section{MATERIAL AND METHODS}

The experiment was conducted at the Andressa farm, located in the city of Ribas do Rio Pardo, Mato Grosso do Sul state, Brazil, from March to September. Nellore steers, with an average body weight of $382.4 \pm 32.9 \mathrm{~kg}$ and 24 months of age, were evaluated in two 50 hectares (ha.) pastures of $U$. brizantha 'MG-5' (syn. Brachiaria brizantha), previously deferred for 60 days, in the period between March and May. The experimental period was 94 days, from June to September.

The experimental design was completely randomized, where the animals were distributed in two treatments with supplements containing 30 and $40 \%$ crude protein (CP). Cattle were distributed in two previously deferred pastures of grass Uruchloa brizantha 'MG-5' (syn. Brachiaria brizantha), with initial stocking rate of $0.77 \mathrm{AU} / \mathrm{ha}$ (45 animals in each picket), and provided with feeders and drinking fountains. The ad libitum supplement was given daily at 9 a.m. for 94 days in a plastic feeder with an availability of $20 \mathrm{~cm} /$ animal. Weekly collection of leftover foods was performed. Based on the difference between the total supplement provided during the week and the collected leftovers, it was possible to determine the weekly consumption of the supplement and compare means of supplement consumption by the animals. In the statistical model of the comparison of consumption, the week was considered as the unit of repetition.

All animals were previously weighed, identified, and screened, and the daily operations followed the recommendations of Ludke et al. (2012). The animals were treated according to the guidelines of the Ethics, Bioethics and Animal Welfare Committee of the Brazilian Council of Veterinary Medicine and slaughtered in a commercial refrigerator with federal inspection (ROÇA, 2001; CFMV, 2012). The research project was approved by the Ethics Committee on Animal Use (CEUA/UFMS) protocol 245/2009.

To obtain the supplements, two mixtures with different combinations of maize, cattle urea and mineral were formulated to obtain supplements with 30 and $40 \%$ of CP (Table 1).

Samples of the experimental picket grass were collected before the animals were allowed to enter and every 28 days thereafter to determine the availability of forage. In each picket, samples were collected within a square of $1.0 \mathrm{~m}^{2}, 5$ $\mathrm{cm}$ from the soil, to quantify the availability of forage per picket, and to separate the leaf, stem, and senescent material. After separation, the samples were identified and then heated to $65^{\circ}$ $\mathrm{C}$ for 72 hours. After pre-drying, the samples were weighed, milled, and analyzed in the laboratory according to the methodologies described by Detmann et al. (2012).

Animal weighings were performed after 16 hours of solids fasting at the beginning, at 45 days, and at the end of the experimental period ( 94 days). The animals were weighed after being brought directly from the pickets in order to account for effects from the pasture.

After reaching approximately $450 \mathrm{~kg}$, the animals were slaughtered in a commercial slaughterhouse. At slaughter, fasting body weight and warm carcass weight were obtained for the calculation of carcass yield and quantity of arrobas (unit of weight, symbol is@, $1 @=15 \mathrm{~kg}$ ) produced. 
Table 1. Ingredients and chemica composition of supplements with 30 and $40 \%$ of CP

\begin{tabular}{|c|c|c|}
\hline \multirow[b]{2}{*}{ Item } & \multicolumn{2}{|c|}{ Protein levels } \\
\hline & $40 \% \mathrm{CP}$ & $30 \% \mathrm{CP}$ \\
\hline Maize $(\mathrm{g} / \mathrm{kg})$ & 666,7 & 750,0 \\
\hline Urea $(g / k g)$ & 119,0 & 89,1 \\
\hline Sulphur $(\mathrm{g} / \mathrm{kg})$ & 11,9 & 8,9 \\
\hline Mineral $(\mathrm{g} / \mathrm{kg})^{1}$ & 202,4 & 152,0 \\
\hline \multicolumn{3}{|l|}{ Chemical composition } \\
\hline DM (\%) & 91,43 & 90,48 \\
\hline $\mathrm{OM}(\% \mathrm{DM})$ & 65,07 & 73,20 \\
\hline $\mathrm{CP}(\% \mathrm{DM})$ & 39,41 & 31,83 \\
\hline NNP (\% CP) & 65,22 & 51,34 \\
\hline $\mathrm{EE}$ & 2,67 & 3,00 \\
\hline NDF & 9,27 & 10,43 \\
\hline Non-fibre Carbohydrate & 49,92 & 56,15 \\
\hline eTDN (\% DM) & 58,16 & 65,43 \\
\hline Starch (\% DM) & 49,03 & 55,16 \\
\hline
\end{tabular}

Table 2. Chemical composition and characteristics of pasture in function of supplements with 30 and $40 \%$ of CP

\begin{tabular}{lcc}
\hline \multirow{2}{*}{ Item } & \multicolumn{2}{c}{ Protein levels } \\
\cline { 2 - 3 } & $40 \% \mathrm{CP}$ & $30 \% \mathrm{CP}$ \\
\hline Chemical composition & & 27,7 \\
DM (\%) & 28,70 & 93,00 \\
OM (\% DM) & 92,90 & 9,45 \\
CP (\% DM) & 9,54 & 2,55 \\
EE (\% DM) & 2,46 & 79,70 \\
NDF (\% DM) & 79,80 & 54,50 \\
ADF (\% DM) & 54,90 & 5,70 \\
Lignin (\% DM) & 5,80 & \\
\hline Pasture characteristics & & $5.135,30$ \\
\hline Total Availability of DM (kg/hectare) & $5.053,20$ & $2,495,50$ \\
Availability of leaves (kg/hectare) & $2.489,45$ & $1.785,00$ \\
Availability of steams (kg/hectare) & $1.787,75$ & 49,80 \\
Leaf (\%) & 49,26 & 34,70 \\
Steam (\%) & 35,37 & 15.50 \\
Senescent material (\%) & 15,37 & \\
\hline
\end{tabular}

The economic evaluation was made in Reais (R\$) and converted to Dollar values $(\mathrm{U} \$=\mathrm{R} \$ 3.25)$. Total expenses (quotations in September 2016) per treatment were calculated by the sum of the items:
(A) Replacement Animal $=$ U\$ 492.31 (quotation in the city of Ribas do Rio Pardo);

(B) Total labor per animal = employee salary (U\$ 292.31) * experimental period (5 months $/ 90$ animals $)=U \$$ 16.24; 
(C) Electric energy = total monthly electric energy / 30 days $\times 94$ days / 90 animals $=\mathrm{U \$} 0.53$;

(D) Pasture $=$ Pasture rent U\$ $6.15 /$ month $\times(5$ months $)=\mathrm{U} \$ 30.75 /$ animal; (E) Expenses with supplement = Treatment $40 \%$ CP $=$ U\$ $0.44 / \mathrm{kg}$ supplement $\times$ daily supplement consumption $\times$ experimental period (94 days); Treatment $30 \% \mathrm{CP}=\mathrm{U} \$ 0.39 / \mathrm{kg}$ supplement $\times$ daily supplement consumption $\times$ experimental period $(94$ days).

The calculation of net gross margin was obtained from the difference between gross revenues and actual operating costs (those costs that actually required cash disbursement). The cost of the arroba was calculated by the ratio between total expenses and total arrobas. The revenue was calculated by the trade value of the arroba (U \$ 43.08) multiplied by the weight of warm carcass (in $\mathrm{kg}$ ) and divided by 15 (conversion of weight to arroba).

The statistical model used was $\mathrm{Yi}=\mu+$ $\mathrm{Si}+$ eij, where: $\mathrm{Yi}=$ is the observation $\mathrm{k}$, referring to the supplement $i ; \mu=$ is the general constant; $\mathrm{Si}=$ is the effect of the supplement containing different combinations of crude protein; eijk = random error associated with each observation Yi.

The data were evaluated through analysis of variance and the means compared by the F-test at the 5\% significance level.

\section{RESULTS AND DISCUSSION}

Significant differences were observed between the mean intake of supplements (Table 3), with values of 0.69 and 2.26 $\mathrm{kg} /$ day for 40 and $30 \%$ CP treatments, respectively. Consequently, there was a higher nutrient intake in animals supplemented with the lower nitrogen:maize ratio (30\% treatment). A potential mechanism that caused these differences involves competition for available nutrients. When the starch:urea ratio is unbalanced, there is less efficiency in nutrient utilization by microorganisms due to the lack of synchronization of ruminal degradation, leading to variations in consumption (REIS et al., 2009).

Table 3. Nutrient intakes and starch:urea ratio of supplements with 30 and $40 \%$ of CP

\begin{tabular}{lccc}
\hline \multirow{2}{*}{ Item } & \multicolumn{2}{c}{ Protein levels $^{1}$} & \multirow{2}{*}{ P-value } \\
\cline { 2 - 3 } & $40 \% \mathrm{CP}$ & $30 \% \mathrm{CP}$ & 0,0001 \\
Supplement intake (kg/day) & $0,69^{\mathrm{b}}$ & $2,26^{\mathrm{a}}$ & 0,0026 \\
DM intake (kg/dia) & $0,63^{\mathrm{b}}$ & $2,04^{\mathrm{a}}$ & 0,0001 \\
OM intake (kg/day) & $0,41^{\mathrm{b}}$ & $1,49^{\mathrm{a}}$ & 0,0001 \\
CP intake (kg/day) & $0,25^{\mathrm{b}}$ & $0,65^{\mathrm{a}}$ & 0,0001 \\
NNP intake (kg/day) & $0,16^{\mathrm{b}}$ & $0,33^{\mathrm{a}}$ & 0,0001 \\
TDN intake (kg/day) & $0,36^{\mathrm{b}}$ & $1,34^{\mathrm{a}}$ & 0,0001 \\
Starch intake (kg/day) & $331,82^{\mathrm{b}}$ & $1208,70^{\mathrm{a}}$ & 0,0016 \\
Urea intake (kg/day) & $74,97^{\mathrm{b}}$ & $181,76^{\mathrm{a}}$ & 0,0001 \\
Starch:Urea ratio & $4,87^{\mathrm{b}}$ & $7,32^{\mathrm{a}}$ & 0,0024 \\
DM intake (\%BW) & $0,15^{\mathrm{b}}$ & $0,49^{\mathrm{a}}$ & 0,0001 \\
OM intake (\%BW) & $0,10^{\mathrm{b}}$ & $0,36^{\mathrm{a}}$ & 0,0001 \\
CP intake (\%BW) & $0,06^{\mathrm{b}}$ & $0,15^{\mathrm{a}}$ & 0,0001 \\
TDN intake (\%BW) & $0,09^{\mathrm{b}}$ & $0,32^{\mathrm{a}}$ & \\
\hline
\end{tabular}

${ }^{\mathrm{T}}$ Averages followed by different lowercase letters on the same line differ by the $\mathrm{F}$ test $(\mathrm{P}<0,05)$.

Starch:Urea ratio $=$ Starch intake $(\mathrm{kg} / \mathrm{day}) /$ Urea intake $(\mathrm{kg} / \mathrm{day})$. 
Protein supplementation has been recommended to improve forage utilization (GÓES et al., 2003; MORAIS et al., 2013), with the priority of meeting the nutritional requirements of ruminal microorganisms, through the adequate supply of degradable protein in the rumen (ÍTAVO \& ÍTAVO, 2005; RIBEIRO et al., 2011).

However, the lack of synchronization and/or excess nitrogen (N) in the exclusively pasture supplement can reduce the efficiency of microbial protein synthesis and/or increase the need for $\mathrm{N}$ excretion via the liver urea cycle, with concomitant energy expenditure for the animal. Both situations negatively influence performance.

Although the supplements and the pasture used had similar nutrient content (Tables 1 and 2) to meet the nutritional requirements of the animals, the use of both were different (Table 3). Thus, the higher consumption of the supplement with $30 \%$ CP may be associated with differences in the carbohydrate profile available for use in the animal's organism and the more optimal starch:urea ratio was provided by the mixture with $75 \%$ maize and $9.91 \%$ urea in the supplement with $30 \% \mathrm{CP}$. In low quality pastures, such as the one offered in this experiment, the fiber content is high and directly affects consumption owing to physical limitation, since its digestion is slower (SCHIO et al., 2011; ÍTAVO et al., 2013). The urea consumption was $182 \mathrm{~g} /$ day for the $30 \%$ $\mathrm{CP}$ treatment and $75 \mathrm{~g} /$ day for the $40 \%$ CP treatment. These consumptions provided a ratio of starch:urea of 4.43 and 6.65, respectively (Table 3).

The higher amount of maize available in the supplement with $30 \% \mathrm{CP}$ (Table 1) probably improved the forage digestibility, since it provided total digestible nutrients (TDN) consumption four times higher than the TDN of the animals that received supplementation with $40 \% \mathrm{CP}$. With this higher energy efficiency and adequate nitrogen content via supplementation, the use of carbohydrates and proteins for microbial protein synthesis is optimized, which allows for a higher rate of degradation and forage passage as a function of the improvements in the digestion of the fibrous fraction. Improvements in microbial efficiency result in increased flow of nutrients to the small intestine, especially of metabolizable protein, since almost all carbohydrates are fermented in the rumen (SILVA et al., 2009).

The higher intake of nutrients due to the increase in supplement consumption contributed to the increase in the average daily gain of the animals (Table 4). Thus, total weight gain (TWG) differed significantly between treatments (P $<0.05)$. The final body weight was higher $(\mathrm{P}<0.01)$ for the animals that received the supplement with $30 \% \mathrm{CP}$ and the higher amount of maize.

These results were expected, since weight gain is directly related to consumption (NRC, 2000); that is, the higher the nutrient intake, the better the performance, depending on the genetic potential of the animal. Our average daily gain (ADG) results are slightly higher than those reported by Sales et al. (2008), who observed gains of 0.5 to 0.6 $\mathrm{kg}$ /day when they provided multiple supplements for bovines finishing in deferred pasture. However, performance responses to grazing supplementation varies in the dry season. Moreover, Zinn \& Garces (2006) have suggested reduced pasture consumption is minimal up to the level of supplementation of $0.3 \%$ of body weight (BW) per day; if supplement consumption increases to levels above $0.3 \% \mathrm{BW}$, then the pasture consumption is significantly reduced. This decrease may even be greater when 
the supply of supplement is $0.8 \% \mathrm{BW}$, because in this point, the biological limit of weight gain of the animals to pasture is close to being reached.

Ítavo et al. (2007a) reported that supplementation of F1 Canchim $x$ Nellore steers grazing on $B$. brizantha at 0.25 or $0.5 \% \mathrm{BW}$ levels did not result in observable differences in gains, which were quite satisfactory, at a mean of 1.05 $\mathrm{kg} / \mathrm{day}$. In our experiment, the mean values of supplement consumption were $0.14 \%$ BW and $0.47 \%$ BW for treatments with 40 and $30 \% \quad \mathrm{CP}$, resulting in average gains of 0.68 and $0.76 \mathrm{~kg} /$ day, respectively.

Table 4. Performance of Nellore steers supplemented in deferred pasture in function of supplements with 30 and $40 \%$ of CP

\begin{tabular}{lccc}
\hline \multirow{2}{*}{ Variáveis } & \multicolumn{2}{c}{ Protein levels $^{1}$} & \multirow{2}{*}{ P-value } \\
\cline { 2 - 3 } & $40 \% \mathrm{CP}$ & $30 \% \mathrm{CP}$ & 0,3052 \\
Initial Body Weight (kg) & $379,51^{\mathrm{a}}$ & $385,20^{\mathrm{a}}$ & 0,0480 \\
Final Body Weight (kg) & $443,84^{\mathrm{b}}$ & $456,66^{\mathrm{a}}$ & 0,0020 \\
Total Weight Gain (kg/animal) & $64,33^{\mathrm{b}}$ & $71,46^{\mathrm{a}}$ & 0,0020 \\
Average Daily Gain (kg/day) & $0,68^{\mathrm{b}}$ & $0,76^{\mathrm{a}}$ & 0,0002 \\
Gain in Arroba (@/animal) ${ }^{\mathrm{b}}$ & $2,25^{\mathrm{b}}$ & $2,51^{\mathrm{a}}$ & 0,2050 \\
Carcass Weight (kg/animal) & $233,37^{\mathrm{a}}$ & $240,43^{\mathrm{a}}$ & 0,2015 \\
Total Arroba (@/animal) & $15,56^{\mathrm{a}}$ & $16,03^{\mathrm{a}}$ & 0,2050 \\
Carcass Yield (\%) & $52,58^{\mathrm{a}}$ & $52,65^{\mathrm{a}}$ & \\
${ }^{1}$ Averages followed by different lowercase letters on the same line differ by the F test $(\mathrm{P}<0,05)$. \\
${ }^{2}$ Gain in Arroba = (Total Weight Gain x Carcass Yield)/15. & \\
${ }^{3}$ Carcass Yield = Warm Carcass Weight/Final Body Weight x 100). &
\end{tabular}

Oliveira et al. (2004) evaluated supplementation for Nellore steers kept in $U$. brizantha pasture at 0.2 and $0.4 \%$ BW levels and did not observe differences in mean daily gains, with averages of 426 and $467 \mathrm{~g} /$ day, respectively. Paulino et al. (2002), in a study evaluating different protein sources as components of supplements for finishing cattle under grazing, observed satisfactory levels of gain, above $1.0 \mathrm{~kg} / \mathrm{animal} / \mathrm{day}$, in the Uruchloa decumbens pasture (syn. Brachiaria decumbens) in the dry period.

Although the performance of the animals supplemented with $30 \% \mathrm{CP}$ was better, the carcass weight, total arrobas and carcass yield values were similar between treatments $(\mathrm{P}>0.05)$. It is probable that higher values of daily weight gain and $30 \% \mathrm{CP}$ final weight gain are associated with a more correct use of nutrients due to a better synchronization of the ingredients of this diet, resulting in slightly higher but not significant values when compared to the $40 \% \mathrm{CP}$ treatment. In addition, the level of variation in carcass characteristics was lower than that observed for the performance data, thus reducing the possibility of finding significant differences between the means of the treatments.

Ítavo et al. (2007b) evaluated the performance of steers treated with two levels of supplementation (1 and 2 $\mathrm{kg}$ /day supplement, with $18 \% \mathrm{CP}$ and $80 \%$ TDN) during the dry season on deferred pastures, and observed that animals supplemented with $2 \mathrm{~kg}$ /day presented similar gains to the animals supplemented with $1 \mathrm{~kg} /$ day. These results differ from those presented in 
Tables 3 and 4, since the animals that consumed $0.47 \%$ BW $(30 \% \mathrm{CP})$ did not exhibit performances close to 1.12 $\mathrm{kg} /$ day, as observed by Ítavo et al. (2007b). These authors also reported the net margin per animal to help evaluate the supplementation levels and found lower values than those presented in Table 5. The differences in the performances of animals between different studies can be attributed to the selectivity of the animals in each experiment, the filling effect caused by grazing, and the type of supplement.

Despite the better productive performance presented by the animals that received the $30 \% \mathrm{CP}$ supplement, the total expenditure and the average daily cost were higher than the treatment with supplement $40 \% \mathrm{CP}$ (Table 5). The averages of total expenses and daily costs of the $40 \% \mathrm{CP}$ treatment were lower (U\$ 568.37 and U\$ 28.34, respectively) than those of the $30 \% \mathrm{CP}$ treatment (U\$ 662.68 and U\$ 82.85, respectively). This was mainly due to the higher consumption of the animals in the $30 \%$ CP treatment, since product prices $(\mathrm{U} \$ / \mathrm{kg})$ were similar, U\$ 0.44 and U\$ 0.39 for treatments $40 \% \quad \mathrm{CP}$ and $30 \% \quad \mathrm{CP}$, respectively.

Table 5. Economic evaluation of Nellore steers supplemented in deferred pasture in function of supplements with 30 and $40 \%$ of $\mathrm{CP}$

\begin{tabular}{lcc}
\hline \multirow{2}{*}{ Item } & \multicolumn{2}{c}{ Protein levels } \\
\cline { 2 - 3 } & $40 \% \mathrm{CP}$ & $30 \% \mathrm{CP}$ \\
\hline Gross Revenues (U\$/animal) & 669,86 & 690,57 \\
Total Expenses (U\$/animal) & 568,37 & 662,68 \\
Expenses with supplement (U\$/animal) & 28,54 & 82,85 \\
Net Gross Margin (U\$/animal) & 101,49 & 67,89 \\
Cost of the arroba (U\$/arroba) & 36,53 & 41,34 \\
Profitability (\%) & 15,16 & 4,03 \\
\hline
\end{tabular}

Consequently, the cost per arroba for the $40 \% \mathrm{CP}$ and $30 \% \mathrm{CP}$ treatments were U\$ 36.53 and 41.34, respectively, influencing the results of total expenses associated with carcass weight and total body weight. The treatment with $40 \%$ CP supplementation provided a higher net margin than for the animals that received $30 \% \mathrm{CP}$ supplementation (U\$ 101.49 vs. U\$ 67.89, respectively). The mineral-nitrogen supplementation at $40 \% \mathrm{CP}$ presented a profitability of $15.16 \%$ versus $4.03 \%$ for the $30 \% \mathrm{CP}$ level, which illustrates the risk of using a certain supplement, since an error in choice would cause a loss in productivity.
We conclude that mineral nitrogen supplementation with either $40 \%$ or $30 \%$ CP provided satisfactory animal performance and carcass characteristics for animals finishing on deferred pastures during the dry season. From the economic point of view, it is recommended to supplement mineral nitrogen with $40 \% \mathrm{CP}$ in finishing of steers in deferred pastures, but ultimate success in reducing production costs in the field depends on the variations in prices between different regions of the country and market opportunities. 


\section{REFERENCES}

CONSELHO FEDERAL DE

\section{MEDICINA VETERINÁRIA - CFMV.}

Guia brasileiro de boas práticas para a eutanásia de animais. 2014. Disponível em:

$<$ http://www.cfmv.gov.br/portal/_doc/gui abbp_eutan $\% \mathrm{C} 3 \% \mathrm{~A} 1$ sia_animal.pdf $>$.

Acesso em: 10 fev. 2015.

DETMANN, E.; SOUZA, M.A.; VALADARES FILHO, S.C.; QUEIROZ, A.C.; BERCHIELLI, T.T.; SALIBA, E.O.S.; CABRAL, L.S.; PINA, D.S.; LADEIRA, M.M.; AZEVEDO, J.A.G. Métodos para análise de alimentos. Instituto Nacional de Ciência e Tecnologia de Ciência Animal, INCT. Visconde do Rio Branco, MG: Suprema, 2012. 214p.

GÓES, R.H.T.B.; MANCIO, A.B.; LANA, R.P.; VALADARES FILHO, S. de C.; CECON, P.R.; QUEIROZ, A.C. de; LOPES, A.M. Desempenho de novilhos nelore em pastejo na época das águas: ganho de peso, consumo e parâmetros ruminais. Revista Brasileira Zootecnia, v.32, n.1, p.214-221, 2003.

ÍTAVO, L.C.V.; ÍTAVO, C.C.B.F. Parâmetros ruminais e suas correlações com desempenho, consumo e digestibilidade em ruminantes. In: ÍTAVO, L.C.V.; ÍTAVO, C.C.B.F. (Eds.) Nutrição de ruminantes: Aspectos relacionados à digestibilidade $\mathrm{e}$ aproveitamento de nutrientes. 1.ed. Campo Grande: UCDB, 2005. p.49-72.

ÍTAVO, L.C.V.; DIAS, A.M.; ANDRESON, H.C; ÍTAVO, C.C.B.F. Terminação de diferentes categorias de bovinos suplementados em pastagens diferidas. Revista Brasileira de Saúde e Produção Animal [online], v.8, n.4 p.309-316, 2007a.
ÍTAVO, L.C.V.; ÍTAVO, C.C.B.F.; DIAS, A.M.; NOVAIS, M.F. de S.M.; SILVA, F.F. da; MATEUS, R.G.; SCHIO. A.R. Desempenho produtivo e avaliação econômica de novilhos suplementados no período seco em pastagens diferidas, sob duas taxas de lotação. Revista Brasileira de Saúde e Produção Animal [online], v.8, n.3, p.229-238, $2007 b$.

ÍTAVO, L.C.V.; DIAS, A.M.; ÍTAVO, C.C.B.F.; EUCLIDES FILHO, K.; MORAIS, M.G.; , SILVA, F.F.; GOMES, R.C.; SILVA, J.P.B.

Desempenho produtivo, características de carcaça e avaliação econômica de bovinoscruzados, castrados e nãocastrados, terminados em pastagens de Brachiaria decumbens. Arquivo Brasileiro de Medicina Veterinária e Zootecnia, v.60, n.5, p.1157-1165, 2008.

ÍTAVO, L.C.V.; SILVA, F.F.; SCHIO, A.R.; ÍTAVO, C. C. B. F.; DIAS, A. M.; NOGUEIRA, E.; LEAL, E. S.; KAVESKI, M. S. Suplementação a pasto: Estratégias nutricionais. In: SIMPÓSIO DE PRODUÇÃO ANIMAL A PASTO, 2, 2013, Londrina, PR. Anais... Londrina, PR: Nova Sthampa, 2013. p. 199-241.

LUDKE, C.B.; CIOCCA, J.R.P.; DANDIN, T.; BARBALHO, P.C.; VILELA, J.A.; FERRARINI, C. Abate humanitário de bovinos. Rio de Janeiro:WSPA, 2012. 148p.

MATEUS, R.G.; DA SILVA, F.F.; ÍTAVO, L.C.V.; PIRES, A.J.V.; SIVA R.R.; SCHIO, A.R. Suplementos para recria de bovinos Nelore na época seca:desempenho, consumo e digestibilidade dos nutrientes. Acta Scientiarum Animal Sciences, v.33, n.1, p.87-94, 2011. 
MORAES, E.H.B.K.; PAULINO, M.F.; VALADARES FILHO, S. de C.; MORAES, K.A.K. de; DETMANN, E.; SOUZA, M.G. de. Avaliação nutricional de estratégias de suplementação para bovinos de corte durante a estação da seca. Revista Brasileira de Zootecnia, v.39, n.3, p.608-616, 2010.

MORAIS, M. G.; GOMES, C.S.L.; LEMPP, B.; van ONSELEN, V.J.; FRANCO, G.L.; ÍTAVO, L.C.V.; ÍTAVO, C.C.B.F. Consumo e digestibilidade de nutrientes em bovinos submetidos a diferentes níveis de uréia. Archivos de Zootecnia, v.62, p.239246, 2013.

OLIVEIRA, L.O.F.; SALIBA, E.O.S.; RODRIGUEZ, N.M.; GONÇALVES, L.C.; BORGES, I.; AMARAL, T.B. Consumo e digestibilidade de novilhos Nelore sob pastagem suplementados com misturas múltiplas. Arquivo Brasileiro de Medicina Veterinária e Zootecnia, v.56, p.61-68, 2004.

PAULINO, M.F., DETMANN, E., ZERVOUDAKIS, J.T. Suplementos múltiplos para recria e engorda de bovinos em pastejo. In: SIMPÓSIO DE PRODUÇÃO DE GADO DE CORTE, 2, 2001, Viçosa, MG. Anais...Viçosa, MG: UFV, 2001. p.187-231.

PAULINO, M.F., ZERVOUDAKIS, J.T, DE MORAES, E.H.B.K., DETMANN, E., VALADARES FILHO, S.C. Bovinocultura de ciclo curto em pastagens. In: SIMPÓSIO DE PRODUÇÃO DE GADO DE CORTE, 3, 2002, Viçosa, MG. Anais... Viçosa, MG: UFV, 2002. p.153-196.

PROHMANN, P.E.F.; BRANCO, A.F.; PARIS, W.; BARRETO, J.C.; MAGALHÃES V.J.A.; GOES R.H.T.B.; OLIVEIRA, M.V.M..
Método de amostragem e caracterização química da forragem consumida por bovinos em pasto consorciado de aveia e azevém. Arquivo Brasileiro de Medicina Veterinária e Zootecnia, v.64, n.4, p.953-958, 2012.

REIS, R.A.; RUGGIERI, A.C.; CASAGRANDE, D.R.; PÁSCOA, A.G. Suplementação da dieta de bovinos de corte como estratégia do manejo das pastagens. Revista Brasileira de Zootecnia, v.38, n.1, p.147-159, 2009.

RIBEIRO, S.S.; VASCONCELOS, J.T; MORAIS, M.G.; ÍTAVO, C.B.C.F.; FRANCO, G.L. Effects of ruminal infusion of a slow-release polymercoated urea or conventional urea on apparent nutrient digestibility, in situ degradability, and rumen parameters in cattle fed low-quality hay. Animal Feed Science and Technology, v.164, n.1, p.53-61, 2011.

ROÇA, R.O. Abate humanitário de bovinos. Revista educação continuada CRMV-SP, v.4, n.2, p.73 - 85. 2001.

SALES, M.F.L., PAULINO, M.F., VALADARES FILHO, S. de C.; PORTO, M.O.; MORAES, E.H.B.K. de; BARROS, L.V. de. Níveis de uréia em suplementos múltiplos para terminação de novilhos em pastagem de capim-braquiária durante o período de transição águas-seca. Revista

Brasileira de Zootecnia, v.37, n.9, p.1704-1712, 2008.

SANTOS, M.E.R.; FONSECA, D.D.; EUCLIDES, V.P.B.; RIBEIRO JUNIOR, J.I.; MOREIRA, L. de M. Produção de bovinos em pastagens de capim-braquiária diferidas. Revista Brasileira de Zootecnia, v.38, n.4, p.635-642, 2009. 
SCHIO, A.R.; VELOSO, C.M.; SILVA, F.F.; ÍTAVO, L.C.V.; MATEUS, R.G.; SILVA, R.R. Ofertas de forragem para novilhas nelore suplementadas no período de seca e transição seca/águas. Acta Scientiarum Animal Sciences, v.33, n.1, p.9-17, 2011.

SILVA, F.F.; SÁ, J.F.; SCHIO, A.R.; ÍTAVO, L.C.V.; SILVA, R.R.; MATEUS, R.G. Suplementação a pasto: disponibilidade e qualidade $\mathrm{x}$ níveis de suplementação x desempenho. Revista Brasileira de Zootecnia, v.38, p.371389, 2009 (supl. especial).

ZINN, R.A., GARCES, P.

Supplementation of beef cattle raised on pasture: biological and economical considerations. In: SIMPÓSIO DE PRODUÇÃO DE GADO DE CORTE, 2006, Viçosa, MG. Anais...Viçosa, MG: UFV, 2006. p.1-14.

Data de recebimento: 29/09/2016

Data de aprovação: 20/11/2017 